\title{
Opening Up Hispanic Literature: An Open-Access Critical Edition Assignment
}

\author{
Julie Ann Ward, PhD \\ Associate Professor, Department of Modern Languages, Literatures, \& Linguistics \\ University of Oklahoma \\ Madison Doyle \\ Honors Research Assistant, Department of Modern Languages, Literatures, \\ \& Linguistics \\ University of Oklahoma
}

\begin{abstract}
Pedagogical research into cooperative learning and open educational resources supports an expectation for strong learning outcomes in both cases. This article is a guide to the implementation of a group assignment in a college introductory Hispanic literature course where students create critical editions of literary texts. The critical editions project described in this article focuses on team-building and training in group dynamics in addition to the skills of literary research. This project's relationship to the Open Education movement is an important part of its success, in that it both uses Open Educational Resources (OER) through public domain literary texts as the objects of study in the course, and also asks students to produce OER through their critical editions of literary texts in the public domain. In this essay, we describe a group activity in which students in an introductory literature course research and create digital critical editions of literary texts, which are in turn collected and published online in an open-access anthology. Over the course of a semester, students are engaged in establishing and maintaining group dynamics, learning the basic skills of literary research, and presenting their research findings with the goal of creating a public good.
\end{abstract}

Many Spanish degrees granted in the United States require a particular course which may go by one of several names, usually including the terms "Introduction," "Hispanic," "Literature" and "Culture." The course intends to not only introduce students to a wide variety of literary texts in Spanish, but also to train them in the skills of literary analysis. Generally, this course is a gateway between lower-division language skills courses and upper-division literature and culture courses, though there is significant overlap between these focuses throughout the curriculum. The course often includes units on drama, essay, narrative, and poetry and may include a unit on cinema as well. As a bridge between courses that focus mainly on language skills and literature courses, this course presents an opportunity to introduce students to the practice of literary research.

In order to make use of this opportunity, in Ward's sections of SPAN 3853: Introduction to Hispanic Literature and Culture, taught at the University of Oklahoma, students complete an assignment that introduces them to the skills and principles of literary research. The class usually has 24 students, most of whom have taken Spanish courses with a focus on language skills up to this point. They encounter the field of 
Hispanic literary and cultural studies through a group assignment in which students create scholarly editions of Hispanic literary texts for online publication in an openaccess anthology. Each group selects a text from the syllabus; writes a critical introduction on the literary and historical contexts of the text and author; annotates the text with literary interpretations, definitions, and historical connections; and creates discussion questions and a bibliography for further reading. After the editions are turned in and vetted, they are published in the open-access Antología abierta de literatura hispana 'Open Anthology of Hispanic Literature' (AALH). The assignment, therefore, requires an in-depth study of the author's life and literary and socio-historical context of the work in addition to literary analysis and interpretation. By giving students hands-on experience in literary research, this assignment prepares them to undertake later research projects in upper-division literature and culture courses.

In this essay, we describe a group activity in which students in an introductory literature course research and create digital critical editions of literary texts, which are in turn collected and published online in an open-access anthology. We explain the motivations for developing the assignment, give an overview of its implementation, and reflect on student learning and the shift in focus toward students as researchers. This project addresses the challenge of introducing students to literary studies as a field of research. Over the course of a semester, students are engaged in establishing and maintaining group dynamics, learning the basic skills of literary research, and presenting their research findings with the goal of creating a public good. This group project was only one of many activities completed throughout the semester. We provide links to an online critical edition assignment implementation guide, as well as to the current edition of the finished project, the $A A L H$. It is our hope that readers will find inspiration to implement research-based and open-access literature projects in their own classrooms, possibly contributing to the $A A L H$. This project was based on pedagogical research into cooperative learning and open educational resources, which supports an expectation for strong learning outcomes.

\section{Relevant Background Literature}

Much research has been published on the effects of incorporating cooperative learning in the undergraduate classroom. We use Neil Davidson and Claire Howell Major's definition of cooperative learning. In their review of the literature on cooperative learning, they find that

The main idea in all the cooperative learning approaches is that students work and learn together actively in small groups to accomplish a common goal in a mutually helpful manner. Cooperative learning combines active learning and social learning via peer interaction in small groups on academic tasks. (Davidson \& Major, 2014, pp. 14-15)

Cohen and Lotan (2014) advocate for group learning because of its contribution to higher-order, conceptual thinking tasks, stating that "People of any age deal with the uncertainty of a challenging task better if they consult fellow workers or students than if they try to work by themselves" (p. 12). Cohen and Lotan (2014) also find that "Cooperative tasks are an excellent tool for [...] the learning of language and the 
improvement of oral communication skills" (p. 17). Many researchers find that cooperative learning contributes to student success, as the ability to collaborate determines real-world success (Johnson \& Johnson, 1994; Michaelsen et al., 2014; Nilson, 2016). Investigators find that it is, nevertheless, important to implement cooperative learning properly in order to reap the identified potential benefits. For example, several researchers point to the fact that it is necessary to provide what Cohen (1994) calls "training for cooperation" (p. 30). Nilson (2016) recommends that instructors "[t]each [students] some basic principles of group dynamics, like communication patterns" (p. 181). Johnson et al. (2014) advocate for formal learning groups in which instructors take the following steps:

1. Make a number of pre-instructional decisions. [...]

2. Explain the task and the positive interdependence. [...]

3. Monitor students' learning and intervene within the groups to provide task assistance or to increase students' interpersonal and group skills. [...]

4. Assess students' learning and helping students process how well their groups functioned. [...] (pp. 104-105)

The Critical Editions Project described in this article implements the suggestions above, including a focus on team-building and training in group dynamics in addition to the skills of literary research. Additionally, this project could be categorized as what Bennett and Watson (2006) call "Renewable Student Projects," given that it focuses on "entire life cycles, modularization and teamwork, and open source strategies [...]" (pp. 289-290). Although Bennett and Watson's projects deal with information systems development, the principle of the renewable group project nonetheless applies to the Critical Editions Project as well since it also has an open access final product that is updated by students enrolled in future sections of the course, as well as students from other universities.

This project's relationship to the Open Education Movement is an important part of its success in that it both uses Open Educational Resources (OER) ${ }^{1}$ through public domain literary texts as the objects of study in the course and also asks students to produce OER through their critical editions of literary texts in the public domain. Several scholars have demonstrated the benefits of using OERs in the classroom. Hilton (2016) completed a synthesis of 16 studies that examine OERs in higher education contexts and found that "The decision to employ OER appears to have financial benefits to students (and the parents and taxpayers who support them) without any decrease in their learning outcomes" (p. 588). These tentative findings are bolstered by Hilton and Laman's 2012 study showing that students who used an open textbook

${ }^{1}$ OER are defined by the Hewlett Foundation and UNESCO as

teaching, learning, and research resources that reside in the public domain or have been released under an intellectual property license that permits their free use or re-purposing by others. Open educational resources include full courses, course materials, modules, textbooks, streaming videos, tests, software, and any other tools, materials, or techniques used to support access to knowledge. (Atkins et al., 2007). 
rather than a traditional textbook had better outcomes: “The grade point average and final test examination scores of students using the free book improved. Retention rates were also improved in classes that used the open textbooks" (p. 268). Another study by Hilton and others tracked community college students over four semesters and found that those who used OERs in face-to-face courses "do no worse academically" and "were significantly less likely to withdraw from a course and more likely to receive a C or higher in the course than their peers" (Hilton et al., 2016). The authors conclude that their

study adds to the body of research suggesting that OER are a promising avenue for reducing the costs of higher education without compromising academic success. It may be that increasing student access to learning materials is connected with their increased academic success. (Hilton et al., 2016)

UNESCO and Commonwealth of Learning urge academic staff to "Consider publishing OER $[, \ldots$ a]ssemble, adapt and contextualise existing OER $[, \ldots$ and e]ncourage student participation" (2015, pp. 9-10). While OERs are not without their limitations and require careful theorization (Knox, 2013; Olcott, 2012), there are clear academic benefits to their use and production by students.

This article adds to the literature regarding OER use in foreign language classrooms. The Critical Editions Project addresses what Thoms and Thoms (2014) have identified as limitations of OERs by producing student-created OERs that are both level-appropriate and sustainable. Our findings support the idea that OER use in foreign language classrooms benefits from the support of TAs and university librarians (Thoms \& Thoms, 2014, p. 144). Bringing the Open Education Movement to foreign language classrooms stands to benefit students and institutions alike by increasing availability of current, relevant, and free course materials.

\section{Contexts}

The institutional context for this assignment is the University of Oklahoma (OU). OU is the flagship state university, with enrollments of 21,200 undergraduate and 3,707 graduate students on the main campus in Fall 2017. The Spanish program is housed in the Department of Modern Languages, Literatures, and Linguistics (MLLL) and offers BA, MA, and PhD degrees. In 2017, there were 35 bachelor's degrees in Spanish conferred, 3 master's degrees, and 3 doctorates. In 2017, 33\% of students enrolled at the main campus indicated race/ethnicity other than white. In the Department of MLLL in 2017, 34\% of majors self-reported as male and $66 \%$ as female (no majors self-reported as non-binary/not reported). In the same year $49 \%$ of all students reported as male and $50 \%$ as female; less than one percent of students selfreported gender as non-binary/non-reported. Sixty-two percent of students on the main campus were considered state residents for tuition purposes in 2017. The average age of undergraduate students was 21.3 years. There were 1,983 international students enrolled on the main campus. The average class section size in the College of Arts and Sciences was 37.7 students; upper-division Spanish course enrollments are capped at 24 students. The two sections of Spanish 3853: Introduction to Hispanic Literature and 
Culture that completed the assignment described here had 20 and 23 students enrolled at the beginning of the semester.

At OU, where this project was first implemented, the course Spanish 3853: Introduction to Hispanic Literature and Culture is a junior-level course and often the first course students take that focuses principally on literature rather than Spanish language skills (though lower-division language courses do incorporate literature and culture, and upper-division literature and culture courses also emphasize language skills). Most of the students who enroll in this course are third- or fourth-year students; many students, however, take the course as first-year students after having completed a departmental placement exam that indicates they have an intermediate language level. A large number of students who enroll in Spanish 3853 are pursuing a minor or major in Spanish. Spanish 3853 counts as an elective course for the Spanish minor and is a requirement for the major in Spanish. It is also a prerequisite for other upperdivision major courses. Generally, three sections of the course are offered per semester, and all three tend to fill. According to the catalog description, this course

[i]nitiates students into the literatures and cultures of the Hispanic world, both in Spain and Latin America. Teaches how to analyze literature by literary genres and movements. Emphasis on all four language skills (hearing, speaking, reading, and writing) and culture. (Enrollment Services, 2017)

The following paragraph is included in the syllabus for courses taught by Dr. Ward: This course is designed to improve reading comprehension and to introduce the language techniques of literary and cinematic analysis. Representative works from various literary genres in Spain and Latin America will be studied, including narrative, poetry, drama, essay, and film. It prepares students for more advanced analytical and interpretive work in upper-level survey courses in the Spanish major at OU. In addition, students will gain strong analytical skills to apply to many types of written discourse and media.

The course is a three-hour credit course and usually meets face to face on campus two or three times a week for 16 weeks.

While the Critical Editions Project was an important component of the coursework, other activities included: 1 ) regular reading at home and an online preclass reading quiz, which could be taken repeatedly to maximize correct answers; 2) participation in weekly online discussion forums in which students reflected on the readings and respond to each other's posts; 3) a research paper of 2800-3500 words written in Spanish about a literary text, preferably the text that the student's group worked on in the Critical Editions Project; 4) final comprehensive exam with identifications of authors, works, and movements, and essay questions. It is in this context that the Critical Editions Project described here was implemented, though it has also been successfully adopted in similar courses at other institutions with varying student populations and curricula.

\section{Project Description}

The first step for implementing this project is forming student groups. In the first week of the course the instructor followed the suggestions outlined in Oakley et al. 
(2004) for establishing groups, including instructor-formed teams that "are diverse in ability levels and who have common blocks of time to meet outside class" and "avoid isolating at-risk minority students on teams" (p. 11). The instructor used the web-based tools offered by the Comprehensive Assessment of Team-Member Effectiveness (CATME) to create groups of 4-5 members based on compatible schedule availability and avoiding isolating minority students. This same system was later used for peer evaluation. Before class students read a New York Times Magazine article by Charles Duhigg reviewing research about successful groups, "What Google Learned from Its Quest to Build the Perfect Team," in preparation for our discussion of group work. In class we read "Coping with Hitchhikers and Couch Potatoes on Teams" (Oakley et al., 2004, pp. 33-34) and discussed group work in general using these questions:

- ¿Cuál es tu opinión en general del trabajo en equipo en las universidades? [What is your general opinion about group work in college?]

- ¿Cuál ha sido la peor experiencia con el trabajo en equipo que has tenido? ¿Por qué fue dificil? [What is the worst group work experience you've had? Why was it difficult?]

- ¿Cuál ha sido la mejor experiencia con el trabajo en equipo que has tenido? ¿Por qué fue excelente? [What is the best group work experience you've had? Why was it great?]

We discussed strategies for addressing possible difficulties with group work proactively and went over team policies. Each group created a set of "Normas $y$ expectativas del equipo de trabajo" [Rules and expectations for working in the group], and the instructor (Ward) reiterated each group's right to dismiss any group member who was not pulling their weight or each student's right to leave a group under similar circumstances, per Oakley et al.'s instructions. Students discussed their experiences with group work in the past and made plans to avoid pitfalls. Finally, students learned how team evaluations would affect project grades for individuals; if a team member did not receive an average of an $80 \%$ rating from their teammates, they would not get credit for the Critical Editions Project.

The assignment itself is presented to the students as a project that will help them build their skills in literary research and explanation. Its purpose is to create a scholarly, annotated edition of a Hispanic literary text studied in class. This edition will allow future readers to understand allusions and references, literary structures, and socio-historical context. The intended audience of the critical edition is students and teachers of Hispanic literary texts (high school and postsecondary). To frame the project, students were asked to imagine a person coming across their selected text for the first time. What would they need to know in order to have a good understanding of its meaning and significance? Each critical edition was to include the following elements:

1. Introduction. A 300- to 400-word introduction to the text in Spanish. This should include, at a minimum, the following information:

i) Date of publication

ii) Biographical information about the author

iii) Historical context, including location and relevant sociopolitical information 
iv) Relationship to other literary production of the time (e.g., national and international literary movements, other works by the author)

2. Title. The original title of the text and citation of public domain source.

3. Author. The author's name and, in parentheses, their birth and death dates.

4. Annotations. At least ten annotations to the text in the form of footnotes. There should be at least one of each of the following categories:

i) Definition of unusual words, slang, or words in local dialect or languages other than Spanish

ii) Explanation of a literary allusion or historical or geographical reference

iii) Comment on literary style or form, and what it exemplifies or means

5. Image. At least one properly cited image from the public domain that will help readers to better understand some aspect of the selected work. The image should be accompanied by a caption that describes the image as well as its pertinence to the text, and a bibliographic citation.

6. Citations. In-text, parenthetical citations for all bibliographical references, as well as a separate Works Cited page in MLA Style.

In the original implementation of this project, students were not required to write discussion questions about their texts, a task that was added in later iterations.

After dividing into groups and strategizing for successful teamwork, as described above, we dove into the project. The first step was to define the term "critical edition." Students examined several examples of critical editions of Hispanic literary texts using a worksheet (see Appendix A) to guide them. In class, the instructor first elicited preliminary definitions of critical editions. Then, students used the example critical editions to answer the questions on the worksheet. Finally, they presented their editions to the class using their worksheet responses. At this point we revised the preliminary definitions of critical editions, highlighting the distinction between the role of the editor and that of the author. The instructor explained that each group would be creating a smaller-scale version of the critical editions they just examined by choosing one text studied in class that semester and writing an introduction, providing annotations, and including relevant illustrations and bibliography. The instructor also explained that successful entries could form part of an open-access textbook if the students gave their permission.

The next step was for each group to select the text that they would edit for their project. In this case, the instructor had the support of a graduate student to aid in the research project, and each group met with her to discuss their interests and which texts would best suit them. Because students were selecting from the assigned texts, a list of possible choices was created ahead of time during syllabus design. The criteria for assigned texts were:

- Diversity of genres. The course included examples of drama, essay, narrative, poetry, and film, though copyright issues preclude the inclusion of critical editions of films (see "Public domain" below).

- Geographic diversity. The list includes authors from all over the Spanish-speaking world to avoid any regional concentrations. 
- Gender diversity. The list of assigned texts includes as many women authors as men.

- Public domain. Because the students' critical editions would be published as an open-access anthology, it was important that the texts they edited be in the public domain.

- Length. The texts were short enough to be read or viewed in one sitting by a reader at the upper-division level. This included one-act plays, brief letters or essays, short stories, and short poems.

The most challenging part of meeting these criteria was providing equitable representation of women authors whose works are in the public domain due to historic suppression of women's writing. Pollack (2006) argues convincingly that "[t]he public domain is inherently feminist; by enlarging and protecting the public domain, society would move towards a more feminine, i.e., a more humanist, culture" (p. 619) and that "[a] feminist-friendly public domain can be theorized as an owned public domain where the 'ownership' interest each community member holds is the right not to be excluded" (p. 625). The anthologizing effort of the AALH attempts to participate in this kind of public domain, where women writers have the right to inclusion. As Rich (1972) says, "We need to know the writing of the past, and know it differently than we have ever known it; not to pass on a tradition but to break its hold over us" (p. 19). By giving students the freedom to choose from a diverse collection of writers and writings, this anthology contributes to a new and more inclusive conception of the Hispanic literary tradition.

The remaining efforts of the project were divided over weeks 3-10, and involved check-ins on team progress; a visit from the Open Educational Resource librarian, who presented on Creative Commons licensing and public domain; a visit from the subject librarian, who discussed research strategies and MLA formatting; an in-class work day which included a check-list for groups to determine whether they were on track to successfully complete the project; a peer review day in which groups exchanged their complete drafts and gave each other feedback based on the project criteria, within the university Learning Management System (Canvas); and finally the presentation of the final projects. This took the form of a poster-style session in the main campus library. Each group had a screen on which they could display the wordprocessor version of their critical edition. Visitors from the Office of Undergraduate Research and the University of Oklahoma Libraries, as well as the students themselves, engaged with each group to hear what they learned about their author and text. This event was fulfilling for both the instructor and the students; they gave presentations in both Spanish and English, depending on the audience, and were truly authoritative experts on their subject matter. Each section of the class voted for their favorite critical edition, and that group won a "Premio Popular."

The Critical Editions Project was graded on a pass/fail basis (see Appendix B) as part of a specifications grading system. The project counted for $10 \%$ of the student's final grade in the course. For comparison, the research essay accounted for $15 \%$ of the final grade. According to the grading system for the semester, no partial credit was awarded for either the Critical Editions Project or the research essay. Students' work had to meet the assignment criteria in order to be awarded credit. 
Once the semester had ended, Ward worked with two undergraduate research assistants who fact-checked the introductions and annotations, doublechecked the public domain status of the source texts, and formatted the entries to a standard style sheet we developed together. Finally, they uploaded the texts using the Pressbooks platform, developed and supported by the Rebus Community. It has been a distinct pleasure to work with the Rebus Community, who have coordinated the reproduction of this assignment at various institutions around the United States. The resulting critical editions from those institutions are currently being edited and uploaded by volunteers with the Rebus Community, and an update to the $A A L H$ was released in Summer 2018. The Critical Editions Project has enjoyed such success that it

It is our hope that this open educational resource will increase the accessibility of Hispanic literary texts to students and instructors around the world, as well as inspire others to assign the project in their own classrooms... has been adopted for use at our institution and others. It is our hope that this open educational resource will increase the accessibility of Hispanic literary texts to students and instructors around the world, as well as inspire others to assign the project in their own classrooms and contribute to future editions.

\section{Evaluation of Effectiveness}

Three of the professors who brought the Critical Editions Project to their own institutions have shared their experiences implementing the assignment, and their feedback has been used to assess its effectiveness. Pilar Munday, Associate Professor of Spanish at Sacred Heart University, a private institution in Fairfield, CT, noted that Students learned more from this project than from a regular paper. I felt that they learned through each other as they collaborated and the level of enthusiasm was very high. The idea that this could be published in the book we actually used for the class made all the difference, in my opinion. (personal communication, October 29, 2018)

Munday's experience echoes the research findings that promote the creation of authentic products in class as impactful learning experiences.

David Lisenby, Associate Professor of Spanish at William Jewell College, a private liberal arts college in Liberty, MO, was impressed by the students' research experience with the Critical Editions Project. He commented,

Program assessment data previous to this experience had indicated that students did not always feel that they were making progress toward our SPA program learning outcome related to independent research skills and the ability to incorporate research findings into textual analyses. Without a doubt, this project was helpful for equipping students with better research skills. (personal communication, November 8, 2018)

Equipping students with the tools to conduct their own literary research is one of the most positive outcomes of the project and prepares them to continue work in Hispanic literature and culture and other humanities courses. 
Edma Delgado-Solorzano, Assistant Professor of Spanish at the University of Arkansas, Little Rock, an urban public institution, wrote,

By participating in this project, my students learned about critical editions, copyright laws, creative commons, research, writing, and editing. One of the most valuable skills that they practiced this semester was teamwork and executing team projects. During the semester, the students worked together and kept each other accountable for their work. (personal communication, May 10, 2018)

In this class, as in others, the group work element was important for student learning. Collaboration and accountability allowed for creativity and a higher motivation for completing a high-quality assignment.

Instructors were overall satisfied with the Critical Editions Project, but two of them felt that their students' submissions needed further work to be suitable for publication; however, both felt that they should have intervened more in the final stages of the project to achieve better results. One professor's comments address the changes he will make when implementing the project in the future.

One change I will make is to have the "final" draft due a few weeks earlier. I was not satisfied with the level of polish in students' final drafts, and I feel that they need more direct feedback from me in order to make their drafts submission-ready. I likely relied too heavily on the peer review process the first time around. (D. Lisenby, personal communication, November 8, 2018)

Overall feedback indicates that the Critical Editions Project allows students to develop improved research skills and enhance the ability to work in teams. To achieve success, however, it is important to provide students with access to resources and to train students to work in groups before beginning the project. This feedback confirms our own experience and intentions that through implementing a positive group-work experience and providing the opportunity for creating authentic materials, students have improved engagement with course content.

\section{Conclusions}

Impressions of the assignment reveal that it positively contributes to undergraduate attitudes toward literary research and improves their research and writing skills. Through completing this project, students learn the critical skills of literary research, interpretation, and analysis. They may also see their work published in an OER, which motivates them in ways traditional classroom-based assignments do not. In this way, the assignment promotes what Manchón (2011) calls "writing-tolearn" content. Manchón's research shows that "learning and teaching L2 writing may entail the co-existence of aims related to writing itself [. . .], to learning disciplinary subject-matter in the content areas [. . .], and/or to engaging in writing as a tool for language learning [. . .]" (pg. 4). The Critical Editions Project promoted writing for a general and wide audience, learning content and skills in literary studies, and also promoted improved Spanish language skills through writing.

Future research plans include a comparative study on student perception of learning and confidence and student performance between a class that completed the 
Critical Editions Project and a class that instead completed a traditional research paper. Besides the benefits of involving undergraduate students in literary research and producing an authentic and useful OER, described here, we hope to additionally discover the effects of this assignment on student learning.

\section{References}

Atkins, D. E., Brown, J. S., \& Hammond, A. L. (2007). A review of the open educational resources (OER) movement: Achievements, challenges, and new opportunities. https://www.hewlett.org/wpcontent/uploads/2016/08/ReviewoftheOE RMovement.pdf

Bennett, C., \& Watson, R. T. (2006). Renewable student projects: A learning strategy. Communications of the Association for Information Systems, 17(1), 288-298. https://doi.org/10.17705/1CAIS.01713

Cohen, E. G. (1994). Restructuring the classroom: Conditions for productive small groups. Review of Educational Research, 64(1), 1-35. https://doi.org/10.3102/0034654306400100 1

Cohen, E. G., \& Lotan, R. A. (2014). Designing groupwork: Strategies for the heterogeneous classroom ( $3^{\text {rd }} \mathrm{ed}$.). Teachers College Press.

Davidson, N., \& Major, C. H. (2014). Boundary crossings: Cooperative learning, collaborative learning, and problem-based learning. Journal on Excellence in College Teaching, 25(3\&4), 755.

http://celt.miamioh.edu/ject/

Duhigg, C. (2016, February 25). What Google learned from its quest to build the perfect team. The New York Times Magazine.

https://www.nytimes.com/section/magaz ine
Enrollment Services. (2017). Class Details for SPAN 3853. http://www.ou.edu

Hilton, J. L., III. (2016). Open educational resources and college textbook choices: A review of research on efficacy and perceptions. Education Technology Research and Development, 64(4), 573-590.

https://doi.org/10.1007/s11423-016-9434-9

Hilton, J. L., III, Fischer, L., Wiley, D., \& William, L. (2016). Maintaining momentum toward graduation: OER and the course throughput rate. International Review of Research in Open and Distributed Learning, 17(6), 18-27.

https://doi.org/10.19173/irrodl.v17i6.2686

Hilton, J., III, \& Laman, C. (2012). One college's use of an open psychology textbook. Open Learning: The Journal of Open, Distance and e-Learning, 27(3), 265272.

https://doi.org/10.1080/02680513.2012.716 657

Johnson, D. W., Johnson, R. T., \& Smith, K. A.(2014). Cooperative learning: Improving university instruction by basing practice on validated theory. Journal on Excellence in College Teaching, 25(3\&4), 85-118.

Knox, J. (2013). Five critiques of the open educational resources movement. Teaching in Higher Education, 18(8), 821832.

https://doi.org/10.1080/13562517.2013.774 354 
Manchón, R. M. (2011). Situating the learning-to-write and writing-to-learn dimensions of L2 writing. In R. M. Manchón (Ed.), Learning-to-write and writing-to-learn in an additional language (pp. 3-16). John Benjamins Publishing Company.

Michaelsen, L. K., Davidson, N., Major, C. H. (2014). Team-based learning practices and principles in comparison with cooperative learning and problem-based learning. Journal on Excellence in College Teaching, 25(3\&4), 57-84.

https://www.tandfonline.com/toc/cthe20/ current

Nilson, L. B. (2014). Specifications grading: Restoring rigor, motivating students, and saving faculty time. Stylus Publishing.

Nilson, L. B. (2016). Teaching at its best: A research-based resource for college instructors ( $4^{\text {th }}$ ed.). Jossey-Bass.

Oakley, B., Felder, R. M., Brent, R., \& Elhajj, I. (2004). Turning student groups into effective teams. Journal of Student Centered Learning, 2(1), 9-34.
Olcott, D., Jr. (2012). OER perspectives: emerging issues for universities. Distance Education, 33(2), 283-290.

https://doi.org/10.1080/01587919.2012.700 561

Pollack, M. (2006). Towards a feminist theory of the public domain, or rejecting the gender scope of United States copyrightable and patentable subject matter. William \& Mary Journal of Women and the Law, 12(3), 603-626.

https://scholarship.law.wm.edu/wmjowl/

Rich, A. (1972). When we dead awaken: Writing as re-vision. College English, 34(1), 18-30. https://doi.org/10.2307/375215

Thoms, J. J., \& Thoms, B. L. (2014). Open education resources in the United States: Insights from university foreign language directors. System, 45, 138-146. https://doi.org/10.1016/j.system.2014.05.0 06

UNESCO \& Commonwealth of Learning. (2015). Guidelines for open educational resources (OER) in higher education. Authors. (Original work published 2011). http://unesdoc.unesco.org/images/0021/0 02136/213605e.pdf 
Appendices

Appendix A

Worksheet

Nombre:

Exploración de Ediciones Críticas

Grupo:

1. La obra.

¿Cuál es el título de la edición crítica?

¿Quién escribió la obra primaria?

¿De qué género literario parece ser?

\section{La introducción}

¿Quién escribió la introducción a la edición crítica?

¿Cuándo se publicó la obra primaria por primera vez?

¿Qué tipo de información se incluye en la introducción?

\section{El texto}

¿Qué tipo de información se incluye en las notas a pie de la página?

\section{La bibliografía}

¿Se incluye una bibliografía? De ser así, ¿qué tipos de textos se incluyen en la bibliografía?

\section{Otros elementos}

Anota aquí cualquier otro elemento o información que observas en la edición crítica.

\section{Definición}

Con tu grupo, basándose en sus observaciones y conocimiento previo, elaboren una definición para el término "edición crítica": 


\section{Appendix B}

\section{Critical Edition Assignment Sheet}

[NB: There are references to fichas in the grading scheme of this assignment; this comes from Linda B. Nilson's concept of tokens in "specs grading" (Nilson, 2014)]

\section{Edición Crítica}

\section{Critical Tasks:}

Literary Research and Explanation

Purpose:

To create a scholarly, annotated edition of a Hispanic literary text studied in class. This edition will allow future readers to understand allusions and references, literary structures, and socio-historical context.

Audience:

Students and teachers of Hispanic literary texts (high school and postsecondary).

If a person is coming across your selected text for the first time, what do they need to know in order to have a good understanding of its meaning and significance?

\section{Genre-specific Tips:}

- Have a look at this video for an introduction to the genre of edición crítica.

- Check out examples of critical editions of other texts to see what kind of information they include and how they present it. Are glosses provided in the margins? Is historical context provided in footnotes?

- Always keep in mind your audience: future students of [CLASS TITLE]. What information do they need to successfully comprehend, analyze, and interpret the text?

\section{Ideas for Content}

Your critical edition will include the following elements:

- An introduction

- Information on the work's original publication

- Information on the author

- Historical context

- Comments on form and style

- Explanations of allusions or other references

- Definitions of unusual words

\section{Suggestions for Research}

Several people on campus can help you get started with research for your critical edition. You and your fellow group members should meet with:

- me (your professor)

- X(TA)

- Y (subject librarian) 
- Z (digital resources librarian)

- Consultants at the Writing Center

Be sure your information comes from credible sources, and always cite them using MLA style so that future readers can follow your tracks and read what you did if they need more information. Please see these links for more information on how to evaluate and cite sources:

- [Internet Sources from University of Oklahoma Writing Center Website]

\section{Formatting}

You and your group members will produce your critical text on a shared Google Drive document within Canvas.

The document should include the original text. Be sure to preserve formatting where it is critical, such as line breaks in poetry, italics in short stories, or block quotes in essays.

Use Google Drive's footnote function to add critical information. Any information you provide that requires a citation should include an in-text parenthetical citation (see MLA Handbook, Eighth Edition).

Include a Works Cited page at the end of your text that follows MLA Style guidelines. Please include hyperlinks to online sources.

\section{Requirements and Evaluation}

The critical edition will be graded using a pass/fail rubric. Any group whose critical edition does not meet the following criteria may exchange 2 fichas/group member to correct the project and turn in a new version by [DATE].

A passing critical edition will fulfill the following criteria:

1. Introduction. Includes an error-free 300- to 400-word introduction to the text in Spanish. This should include, at a minimum, the following information:

a. Date of publication

b. Biographical information about the author

c. Historical context, including location and relevant sociopolitical information

d. Relationship to other literary production of the time (e.g., national and international literary movements, other works by the author)

2. Title. Includes the original title of the text. (Do not use quotation marks or italics, as you are creating a primary source.)

3. Author. Includes the author's name and, in parenthesis, their birth and death dates.

4. Annotations. Provides at least ten annotations to the text. There should be at least one of each of the following categories:

a. Definition of unusual words, slang, or words in local dialect or languages other than Spanish 
b. Explanation of a literary allusion or historical or geographical reference

c. Comment on literary style or form, and what it exemplifies or means

5. Image. Includes at least one properly cited image from the public domain that will help readers to better understand some aspect of your selected work. The image should be accompanied by a caption that describes the image as well as its pertinence to the text, and a bibliographic citation.

6. Discussion Questions. Include 5-6 open-ended questions for analysis and interpretation of the text. You might look at Bloom's Taxonomy for ideas for the kinds of verbs to use in your questions--try to focus on higher-order tasks like analysis, synthesis, and evaluation.

7. Citations. Includes in-text, parenthetical citations for all bibliographical references, as well as a separate Works Cited page in MLA Style (see Formatting).

8. Presentation. The digital product is presented by the group in a $\sim 7-$ minute presentation of their critical edition to the class. The presentation involves the participation of each group member, and highlights three of their annotations and the group's process for arriving at them.

9. Group Participation. Each group member will be evaluated by their peers on their overall contribution. Group members who receive lower than an 8/10 rating from their team will be required to spend one ficha per point needed to reach the minimum of eight (e.g., a student who receives a 6/10 must spend two fichas to pass this assignment).

\section{Due Dates [FILL IN FOR THE FOLLOWING ASSIGNMENTS]:}

- Meet in group with instructor/TA to determine subject work for critical edition.

- Complete Team Work Analysis and Review Process in class

- Mid-term Peer Evaluation Due

- Meet with instructor/TA; Go over draft of introduction and list of 10 planned annotations

- Bring seven printed copies of your scholarly edition to class for peer review (4-5 for peers, one each for instructor and TA).

- Final version of Edición Crítica Due; In-class Presentations of Ediciones Críticas

- $\quad$ Final Peer Evaluation Due 
Appendix C

Template for Critical Edition

\author{
Ejemplo del Formato de la Edición Crítica
}

Fulana de Tal, Fulano de Cual, Zutano de Tal y Mengana de Cual

Profesora $\mathrm{X}$

Clase 1234

24 de octubre de 2016

\title{
“Título de obra": Edición crítica
}

Introducción. Lorem ipsum dolor sit amet, consectetur adipiscing elit. Maecenas ultricies fringilla rhoncus. Cras enim odio, placerat a volutpat eu, congue nec mi. Integer orci orci, dapibus at dictum quis, commodo eget ante. Etiam ac ipsum tellus (Álvarez). Proin venenatis porta elit, in tempor risus venenatis vel. Sed maximus, augue at efficitur pellentesque, ipsum quam interdum ante, at mattis odio odio eget urna. Sed non sagittis odio, vitae aliquam lectus. Aenean dapibus, lacus in mattis aliquam, magna arcu vestibulum augue, non imperdiet dolor dui ac lorem (Beltrán). Morbi cursus odio in bibendum iaculis. Nam cursus, velit id tempus mollis, sem neque bibendum ipsum, vel venenatis elit tellus vitae mauris. Aenean quis libero quam. Vestibulum ante ipsum primis in faucibus orci luctus et ultrices posuere cubilia Curae (Cordero 28); Phasellus id condimentum sem, non tincidunt orci (Domínguez Fernández 34). Nam feugiat erat a velit imperdiet, ut rhoncus magna tincidunt.

\section{Figure 1}

Library de Stewart Butterfield. Imagen utilizada bajo licencia CC BY http://bit.ly/2dDkN8V

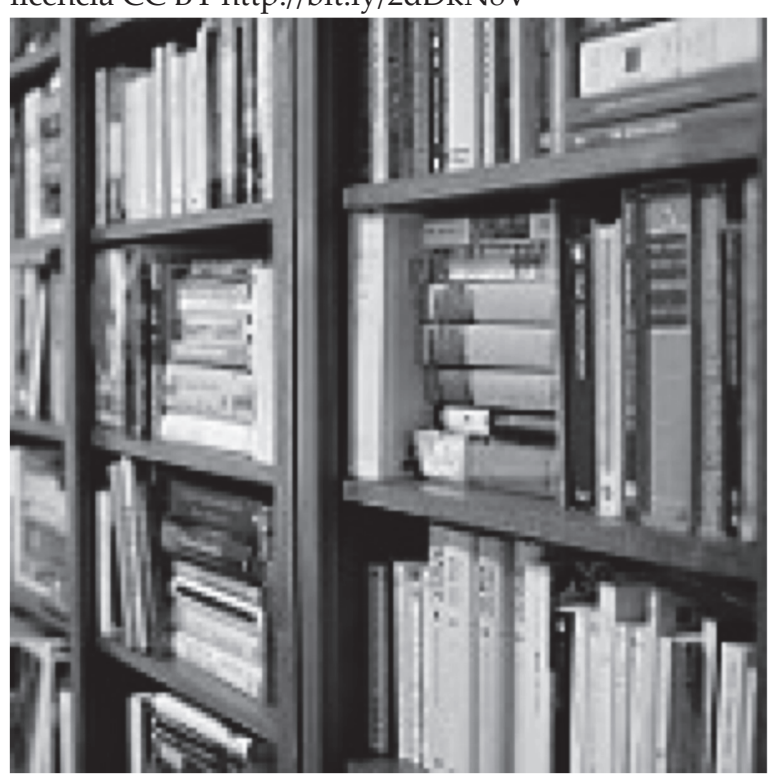

Sed dolor nisl, condimentum vitae sem ut, commodo consequat urna. Ut neque sem, interdum quis orci sit amet, consequat consectetur nulla. Sed efficitur orci nec leo congue, in scelerisque nibh fermentum (García y Hernández "Proin malesuada" 63). Vivamus sollicitudin placerat odio (García y Hernández "Sed elementum" 1283). In in nunc erat. Integer molestie vehicula feugiat. Etiam iaculis a diam sed porttitor. Sed ultrices pretium ipsum et pretium. Maecenas accumsan sapien ac orci elementum finibus (Irving 98). Vestibulum euismod leo a 
turpis malesuada laoreet. Proin elementum magna sit amet tristique eleifend.

Nullam eros orci, vulputate eu tellus a, ullamcorper eleifend sem. Nam rutrum risus sit amet turpis lobortis semper. Duis congue sollicitudin arcu, vitae hendrerit eros auctor ut. Maecenas ut imperdiet mauris, id eleifend massa (Lamar). Mauris lobortis leo sem, id ullamcorper tortor aliquet ut. Duis lobortis massa ac erat pellentesque efficitur (Marín 43). Nullam vestibulum libero nec sem auctor ornare. Vivamus sodales enim id lobortis fringilla. Curabitur nulla diam, porta vitae mi eget, gravida mattis sem.

Vivamus nisl purus, dapibus sed blandit et, suscipit non augue. Cras nec aliquet urna. Nulla ut nunc massa. Nulla pulvinar maximus arcu id consequat. Fusce id dui venenatis, venenatis leo vitae, varius mauris. Vivamus rhoncus tortor nibh, vel pulvinar lorem tristique eu (Irving 99). Donec accumsan metus feugiat rutrum tempus. Praesent eget accumsan nisl, in dictum est. Donec mauris enim, ullamcorper eget est vel, feugiat imperdiet metus. Nam lacus ligula, maximus imperdiet pulvinar sagittis, dapibus eu elit. Integer vitae imperdiet justo. In facilisis aliquet nunc (Núñez 333). Vivamus condimentum scelerisque ante nec iaculis. Mauris vel rutrum lorem. Praesent aliquam finibus tortor in pretium. Sed ut mi auctor, scelerisque tellus quis, congue justo. Quisque semper pulvinar.

"Título del texto"

Nombre y Apellidos del Autor

Lorem ipsum dolor sit amet, consectetur adipiscing elit. Fusce id nunc ultrices, placerat enim vitae, pretium velit. Donec a sem pellentesque, placerat libero sed, molestie augue. Donec ut magna eget urna placerat vulputate.

Cras eu mauris pretium, venenatis nisi ac, dictum nunc. Proin interdum turpis ullamcorper Faucibus Sagittis.

Sed a felis consequat, gravida sapien non, vestibulum orci.

Phasellus eget lectus vel massa faucibus eleifend.

Vestibulum cursus ipsum sed dolor mattis, sit amet interdum ligula tristique.

Etiam volutpat ligula id felis suscipit ornare.

Donec eget turpis placerat, sagittis dui at, iaculis nisl.

Sed eu magna porttitor, consectetur elit in, efficitur lacus.

Proin ornare tortor vitae felis consequat suscipit non ut augue.

Aliquam nec velit finibus, tempus arcu vel, efficitur felis.

Preguntas de análisis e interpretación

1. Describe el uso de .... en el texto.

2. Da ejemplos del texto de...

3. ¿Cuál es la relación entre ... y ... en el texto?

4. Compara y contrasta la representación de ... y ... en el texto.

InSight: A Journal of Scholarly Teaching 
5. Crea una respuesta al poema desde la perspectiva de ...

6. ¿Cuál es el mensaje principal del poema en tu opinión? Justifica tu respuesta con ejemplos textuales.

$$
\text { Bibliografía }
$$

Álvarez, C. (2007, 22 mayo). Sed vitae libero finibus odio laoreet tincidunt at a quam. The New York Times, www.nytimes.com/2007/05/22/science/ear th/22alver.html?_r=0. Accedido 12 mayo 2016.

Beltrán, R. (2006, 1 junio). Reseña de Phasellus mattis mauris, Dirigido por Daniela Gutiérrez. rogeliobeltrant.com, http://www.rogeliobeltran.com/resenas/P hasellus-mattis-mauris-2006. Accedido 15 junio 2016.

Cordero, J. (2007). Aenean quis nisi egestas nibh facilisis hendrerit in sed est. Revista Internacional de Literatura, 14(1), 27-36.

Domínguez Fernández, M. (2005). Proin lacinia metus vel tincidunt placerat. Springer.

García, G., \& Hernández, D. (2006). Proin malesuada: Quisque non risus ut dolor egestas hendrerit. Nuevas Perspectivas, 23(4), 63.
Irving, A. (2016, 1 junio). Mauris pulvinar ligula id quam pulvinar. Vivamus Pulvinar Sem,

www.edf.org/blog/2016/06/01/Maurispulvinar-ligula-id-quam-pulvinar. Accedido 19 julio 2016.

Lamar, B. C. (2007, 17 mayo). Suspendisse iaculis massa feugiat. The New York Times, www.nytimes.com/video/world/americas /1194817109438/suspendisse-iaculismassa-feugiat.html. Accedido 29 julio 2016.

Marín, B. (2007). Nam aliquet eros eget justo convallis. Sed Cursus Leo, 142(17), 3756. Ebsco, Access no: 24984616.

Núñez, H. (2003). Duis eu arcu congue. Cambridge UP.

Phasellus mattis mauris [vídeo]. (2006). Dirigido por Daniela Gutiérrez, Paramount.

Sed elementum. (2001). Letras, 294(5545), 1283-84. doi: 10.1126/letras.1065007

\section{Licencia CC.}

Esta obra está bajo una licencia de Creative Commons Reconocimiento 4.0 Internacional.

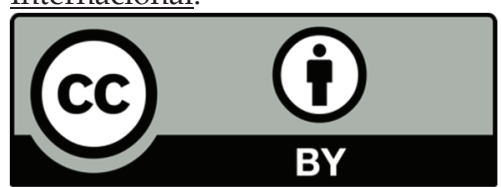


Julie Ann Ward (PhD, Hispanic Languages and Literatures, U of California, Berkeley, 2013) is Associate Professor of Spanish at the University of Oklahoma in Norman. Her research and teaching focus on contemporary Latin American literature and culture, particularly Mexican theatre, performance, and narrative. She is the general editor of the Antologia abierta de literatura hispana, a student-generated Open Educational Resource, and the author of A Shared Truth: The Theater of Lagartijas Tiradas al Sol (U of Pittsburgh Press). Her articles have appeared in Latin American Theatre Today, Revista de Literatura Mexicana Contemporánea Theatre Journal, and TransModernity.

Madison Doyle is an undergraduate Research Assistant at the University of Oklahoma in Norman. She is a senior pursuing majors in Linguistics and International Security Studies with minors in Spanish and Arabic.

"SoTL made me a more reflective teacher and forced me to examine my practices in the classroom...[and] provided me with a deep sense of satisfaction that I am part of a continuous exploration of teaching and learning."

Diana Sturges (2013). To SoTL or Not to SoTL? International Journal for the Scholarship of Teaching and Learning 